\title{
Fleksibel webundervisning vokser med opgaverne
}

\section{Programmeringskursus -}

et eksperiment i netstøttede undervisningsforløb

\section{Turid Fennefoss}

it-vest

tfn@it-vest.dk

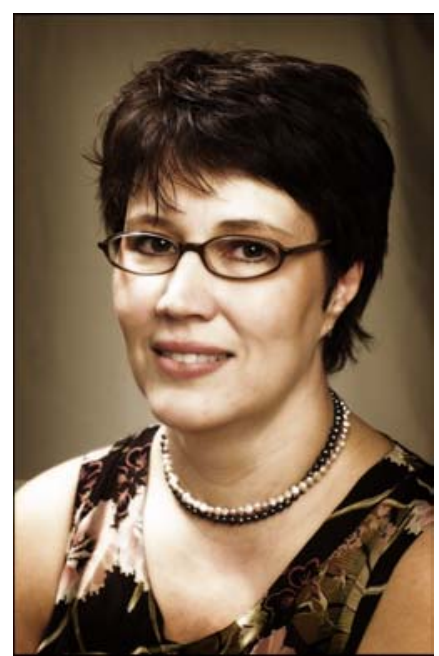

Turid Fennefoss er journalist og Kommunikationschef ved it-vest.

\section{Jens Bennedsen}

it-vest

jbb@it-vest.dk

http://www.daimi.au.dk/ jbb

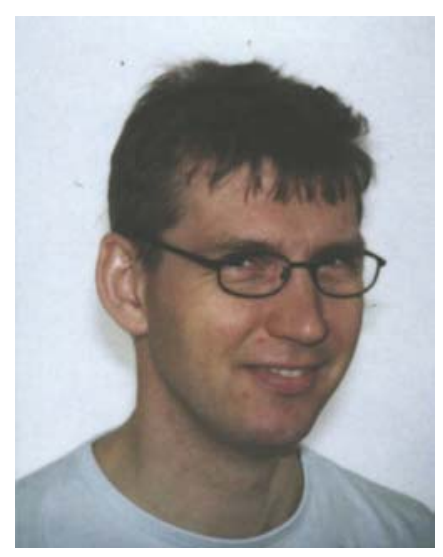

Jens Bennedsen er Cand.scient. og projektleder på it-vest. Har over 15 års undervisningserfaring inden for datalogiske emner. Forsker i muligheder og udfordringer ved introducerende programmeringsundervisning, herunder hvorledes fleksibilitet og netstøtte kan anvendes indenfor konstruktionsorienterede fag. 
Er det muligt at omsætte praktisk orienterede kurser til netstøttede undervisningsforløb og på den måde udvikle og udfordre form, koncepter for teknologianvendelse, didaktisk tænkning og læring? Udfordringen er stor, netop når der er tale om kurser, der dybest set er egentlig mesterlære, hvor den studerende lærer af eksemplets magt.

Og er der overhovedet nogen grund til at fortsætte ad denne vej, når vi i Danmark har relativt korte afstande og generelt gode muligheder for at tage en videregående uddannelse?

Ja, mener Jens Bennedsen og Michael Caspersen, begge undervisere ved Datalogisk Institut på Aarhus Universitet. Deres ønske er at udfordre og udvikle undervisningsformerne på netop de praktisk orienterede kurser. Som prøveballon blev Java-programmeringskurset Introducerende Objektorienteret Programmering valgt. Et grundkursus i programmering, som henvender sig specifikt til voksne deltidsstuderende med vidt forskellig baggrund, hovedparten med en humanistisk uddannelse.

Forløbet blev afviklet som en del af it-vest projektet Flexnet. Et projekt, der blev igangsat i 2001 og som har til formål at udvikle og realisere fleksibel, netstøttet undervisning af høj kvalitet og samtidig tage stilling til aktuelle problemstillinger omkring denne form for undervisning. (se http://qp.ell.auc.dk/flexnet).

Forskere og undervisere bag en række af it-vests eksisterende efter- og videre- uddannelser er gået med i projektet for at bidrage til udviklingen af højkvalitets, netbaseret undervisning i Danmark. I alt 12 uddannelsesgrupper fra it-vests fire institutioner medvirker i projektet, som løber frem til sommeren 2004. Desuden er der i projektet nedsat en række tværgående grupper, som arbejder med problemstillinger i forbindelse med at gøre undervisningen mere fleksibel (se Collis \& Morren 2001). Ud over de konkrete omlægningsprojekter arbejdes der i Flexnet-projektet også med e-learning på forskerniveau, og der er i den forbindelse en antologi under udarbejdelse.

\section{Kursets opbygning og forløb}

I det konkrete eksempel, Introducerende Objektorienteret Programmering, blev der arbejdet med en gruppe voksne studerende fra mange forskellige studieretninger. De studerende havde således meget forskellige forudsætninger for at gennemføre kurset. Deres ønsker og krav skulle passes ind i en målsætning om kvalitet og fleksibilitet, samtidig med at der var tale om studerende med vidt forskellige forudsætninger for at lære programmering. Allerede med den konventionelle undervisningsform havde det været en stor udfordring at formidle kursets indhold til de studerende, der mødte op med en ren humanistisk baggrund. Om undervisningen kunne overføres til et netstøttet undervisningsforløb - uden at indlæringen af stoffet gik tabt for denne gruppe - var derfor en udfordring at afdække.

Et kulturchok, er det introducerende programmeringskursus ofte blevet kaldt. Kurset er et intensivt forløb, hvor den studerende lærer grundlæggende programmering. I programmering eksisterer kun rigtig og forkert. Det kan ikke diskuteres, og selv den mindste unøjagtighed kan resultere $i$ en alvorlig fejl, som hindrer programmet $i$ at fungere. En verden specielt studerende med en humanistisk baggrund kan have svært ved at leve sig ind i og acceptere. I den sammenhæng er det vigtigt, at den studerende straks i starten af forløbet lærer at acceptere, at nok er der forskellige muligheder i valg af udformningen af et program, men det ændrer ikke ved præcisionskravene. 
At det i web-sammenhæng desuden er af yderste vigtighed at sikre, at den studerende ikke kommer til at stå alene med sine frustrationer og usikkerhed, var også kursusledernes holdning fra starten. Et forhold der ikke lettes af at fjerne den direkte kontakt mellem underviser og de studerende. Og dog. Med et webbaseret kursus sættes den enkelte studerende i centrum, og det bliver muligt med en meget høj grad af differentiering i undervisningen, hvor den enkelte har mulighed for maksimalt udbytte. Det var udgangspunktet for kursuslederne.

Derfor blev det besluttet, at web-undervisningen skulle tage afsæt i de muligheder, der er i netstøtten - i stedet for at finde ud af, hvordan man kan "lappe" på de mangler, der unægteligt vil forekomme ved denne form for undervisning.

Det resulterede i et kursus baseret på videomedieret undervisning, et såkaldt $24 * 7$ klasseværelse klassen du er i 24 timer i døgnet, 7 dage om ugen.

Desuden blev de studerende tilbudt mere traditionelle elementer af netstøttet undervisning, som for eksempel tekstbaseret diskussionsforum og weekendseminarer. Denne type undervisning blev anvendt på mere traditionel vis - diskussionsforumet til faglige diskussioner, hvor tiden til refleksion er vigtig, og weekendseminarerne dels til mere livlige diskussioner dels til at fremme en socialisering mellem de studerende. Kurset blev afrundet med en eksamen, hvor den studerende skulle modificere en af de opgaver der var stillet i løbet af kurset. I eksamenssituationen sad den studerende ved en computer i eksamenslokalet og lavede konkrete ændringer eller udvidelser til programmer, mens han brugte teorien til at motivere og argumentere for det, han gjorde. (Om kurset, se Bennedsen \& Caspersen 2003)

\section{Video som undervisningsform}

En af de første observationer, der blev gjort, var en af de traditionelle problemstillinger ved programmeringsundervisningen: at der skal undervises i både begreber og konstruktionsproces. Specielt de procesorienterede aspekter er vanskelige at honorere med traditionelle, trykte materialer. Her kom muligheden for at bruge streamede videoer ind som løsning. Undervisningsformen blev anvendt dels som live-streaming på en række ugentlige videomedierede møder, dels som en række forud producerede videomedierede undervisningsmaterialer. På de ugentlige videomedierede møder kunne de studerende se underviserens skærm og høre hans stemme direkte, og de havde så mulighed for at stille spørgsmål til og kommentere de ting, der blev gennemgået, mens undervisningen foregik. De forudproducerede undervisningsmaterialer viste konkrete anvendelseseksempler på de begreber, der blev gennemgået i pensum.

Både ugemøderne og de forudproducerede videomedierede materialer illustrerede programmeringsprocessen (i modsætning til traditionelle tekstbaserede undervisningsmaterialer der fokuserer på begreberne) for at de studerende på denne måde kunne få et indblik i, hvordan underviseren (= mesteren $\mathrm{i}$ et mesterlæreforløb) arbejder med at opbygge et program på sin pc.

Resultatet var en art videomedieret mesterlare, hvor de studerende dels arbejdede direkte sammen med underviseren og med hinanden, dels havde mulighed for at vende tilbage til sessionen og repetere stoffet.

Formen gav de studerende vigtig indsigt i processen, for eksempel fremgik det med al ønskelig tydelighed:

- at man konstruerer et program i små bidder og ikke ved at lave det hele på en gang,

- at det er naturligt at begå fejl, som man senere retter,

- at en ny tilføjelse kan medføre, at man skal ændre i noget, man allerede har lavet. 
Her var det formen der gjorde, at undervisningen blev mere effektiv og samtidig fleksibel med hensyn til tid og sted.

Samtidig gjorde optagelsen af møderne det muligt for de studerende at vende tilbage og repetere hele eller dele af sessionen for at få det optimale udbytte. Det synkrone live-streaming undervisningsforløb blev således efterfølgende tilgængelig som asynkront undervisningsmateriale.

\section{De studerendes oplevelse af forløbet}

En af de studerende på kurset var Poul Grønkjær, der som masterstuderende i Multimedier med en baggrund som cand.mag. i kultur og æstetik med bifag i dramaturgi er en typisk deltager. Som mange af sine studiefæller havde han ikke på forhånd nogen "naturlig" indgang til begrebet programmering.

Hans vurdering af kurset giver, sammenholdt med den generelle holdning hos de 29 deltagere, således et ret præcist billede af kurset: Noget af undervisningen lykkedes over al forventning, så læreprocessen blev forbedret af, at kurset var netstøttet, andet var lige så vellykket som på et traditionelt kursus, mens andre dele ikke fungerede optimalt.

Han er ikke i tvivl om, hvad der er vigtigt, når han skal give sin vurdering af kursets forløb:

- Face-to-face introduktion med social vægt er en vigtig basis for aktiv deltagelse i de virtuelle læringsrum,

- tillid og fortrolighed til hinanden og teknikken.

At kursets start var præget af både frustrationer og begyndervanskeligheder, lægger Poul Grønkjær ikke skjul på. Som studerende peger han derfor på vigtigheden i, at teknikken fungerer som den skal på forhånd, så de studerende skånes for frustrerende oplevelser i den sammenhæng.

Med tekniksiden i orden viste det sig hurtigt, at specielt idéen om live-streaming, hvor de studerende og underviseren var på nettet samtidig i en egentlig undervisningssituation, fungerede næsten optimalt. Her peges især på vigtigheden i, at underviseren føler sig hjemme i dette forum og er i stand til at formidle i op til en time uden at have øjenkontakt og modspil fra fysisk tilstedeværende elever. Underviserne omstillede sig til undervisningsformen gennem kurset og lærte at gebærde sig i dette forum, hvilket gav deltagerne en fornemmelse af at være personlige modtagere af undervisningen, på samme måde som hvis de fysisk havde været til stede i samme lokale.

At live-streaming sessionerne sideløbende blev optaget, så de studerende efter behov kunne vende tilbage og repetere stoffet, blev opfattet som et yderligere plus. Kombinationen fungerede så godt, at Poul Grønkjær ikke tøver med at påstå, at indlæringspotentialet ved denne undervisningsform for ham var bedre, end det ville have været $\mathrm{i}$ et fysisk klasseværelse, da man i det virtuelle klasseværelse kan eliminere alle former for støj og afbrydelser. Kombineret med muligheden for at vende tilbage til sessionen senere, gav det et maximalt udbytte.

Poul Grønkjærs kommentarer deles af de fleste studerende. Ved afslutningen af kurset blev foretaget en spørgeskemaevaluering af forløbet, hvor der blandt andet blev spurgt ind til brug og udbytte af dels de videomedierede møder, dels de videobaserede materialer. De studerendes vurdering af de videomedierede møder kan ses i figur 1 og 2 - vurderingerne for de videobaserede materialer kan ses i figur 3 og 4. Spørgeskemaet blev besvaret af godt $50 \%$ af de studerende der gik til eksamen (13 ud af en samlet population på 25). 


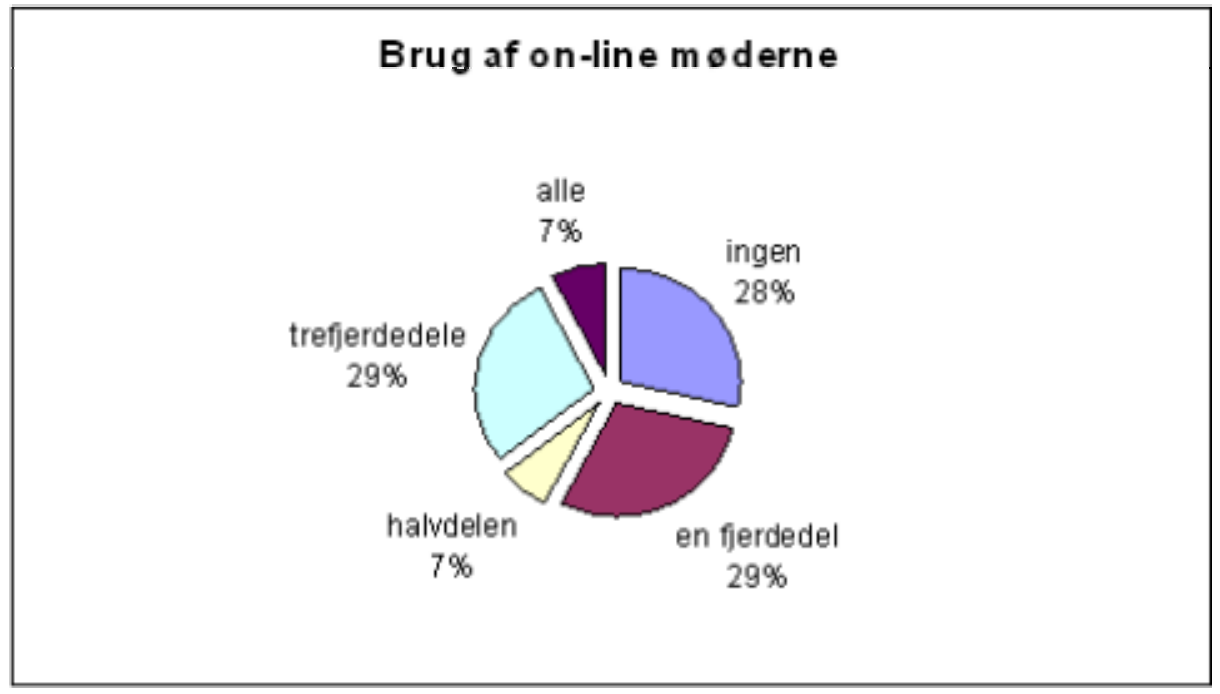

Figur 1: De studerendes brug af videomedierede møder

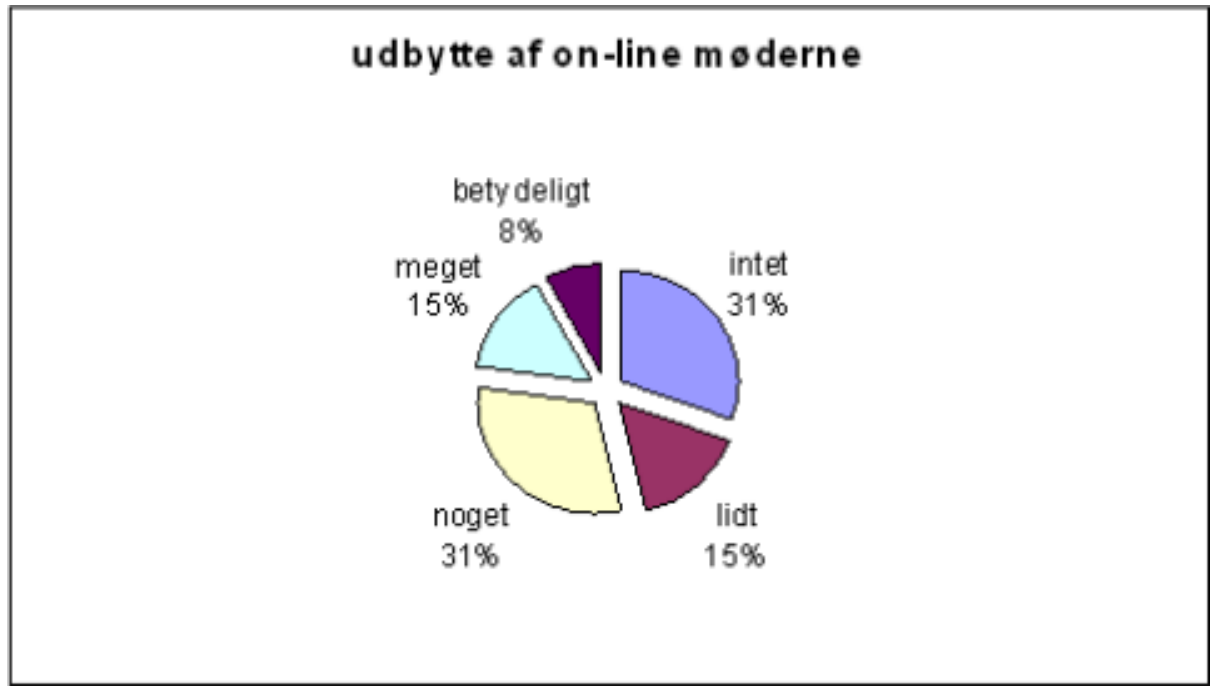

Figur 2: De studerendes vurdering af deres udbytte af videomedierede møder 
Hvor stor en del af de videobaserede materialer har

du set

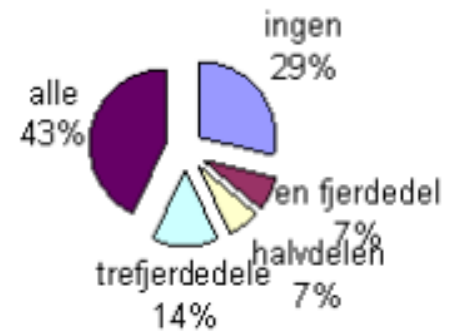

Figur 3: De studerendes brug af de videomedierede materialer

\section{Hvor stor udbytte har du haft af de videobaserede materialer}

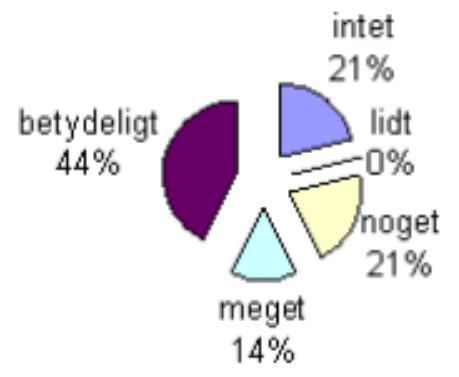

Figur 4: De studerendes vurdering af deres udbytte af videomedierede materialer

Mens selve undervisningsformen betegnes som en positiv oplevelse, fungerede de studerendes chat-funktion til gengæld ikke efter hensigten. Ideen var, at der skulle opstå et dialogpræget forløb gennem undervisningen. Men som studerende oplevede Poul Grønkjær, at de studerendes skriftlige - og derfor langsomme - chatforum slet ikke kunne spille sammen med underviserens mundtlige udtryksform. Et problem der blev forstærket af op til 15 sekunders forsinkelse i transmissionen af live-streamingen. Derfor blev resultatet, at undervisningen i højere grad fungerede som forelæsninger med mulighed for at stille spørgsmål - og i den sammenhæng fungerede livestreaming optimalt, mener han.

Formen på undervisningen gav den fleksibilitet, de studerende ønskede, hvilket evalueringen efter kurset også understregede. Kun 23 procent af de studerende der har svaret på evalueringen udtrykte at deres mulighed for deltagelse var lidt eller meget mindre end et traditionelt kursus 
(traditionelt kursus vil i denne sammenhæng sige et kursus hvor der er undervisning to aftener om ugen). Samtidig betød struktureringen af kurset med ugentlige synkrone, videomedierede møder, at de studerende blev "holdt til ilden". Dette blev yderligere understøttet af, at de studerende skulle aflevere en lille opgave hver uge via et web-baseret opgaveafleveringssystem. Opgaverne skulle godkendes, for at den studerende kunne indstilles til eksamen.

Hvor live-streaming viste sig at være et næsten optimalt værktøj i web-undervisningen, udtrykkes der langt mere skepsis over for det $24 * 7$ klasseværelset. Begrebet beskrives generelt af de studerende i evalueringen som en undervisningsform, der kræver både udvikling og fokus på de studerendes sociale engagement.

24*7 klasseværelset blev realiseret ved, at alle studerende blev registreret i Yahoo-messenger, så de andre i klassen kunne se, hvem der var online på et givet tidspunkt. Filosofien var så, at man havde mulighed for at spørge sin "sidekammerat" via dette system, på samme måde som man har mulighed for at spørge sin sidekammerat i en traditionel undervisningssituation. På chat-planet skete det i et synkront forum, som blev suppleret af et diskussionsforum, hvor spørgsmål og problemstillinger blev gemt, så andre studerende kunne hjælpe og supplere med kommentarer. Igen giver teknologien mulighed for andre interaktionsformer, som kan anvendes i den pædagogiske tilrettelæggelse og gennemførelse af kurset.

Fra en studerendes synspunkt fungerede ideen dog ikke optimalt i pædagogisk sammenhæng. Teknisk set var der kun få problemer med at realisere undervisning i denne form. Efter lidt begyndervanskeligheder fungerede teknikken stabilt, og alle studerende mestrede den. Der blev arbejdet synkront med yahoo-messenger og asynkront med diskussionsforum, og værktøjerne supplerede hinanden fint, men anvendelsen var begrænset, da det for de fleste var nyt og usikkert at agere $\mathrm{i}$ disse fora.

Skønt teknologien var ideel, skulle de studerende lære at bruge den, og her fik det stor betydning, at holdet var sammensat af studerende med vidt forskellige baggrund. Tillid og fortrolighed er vigtige parametre i denne sammenhæng, og for de studerende var oplevelsen, at et manglende kendskab de studerende imellem satte klare grænser for udbyttet af undervisningen. 24*7 klasseværelset er gentagne gange blevet udråbt til at være det ideelle forum til problemløsning, hvis man er fastkørt som studerende. Det giver mulighed for, at man kan spørge sin "sidekammerat", men man gør ikke brug af denne mulighed, hvis man ikke er fortrolig med vedkommende. Det pædagogiske resultat blev, at holdet følte sig på udebane her - både undervisere og studerende, er Poul Grønkjærs opfattelse. Denne opfattelse svarer godt til den generelle opfattelse blandt de studerende, hvor kun 23 procent (ifølge evalueringen) har brugt Yahoo-messenger meget eller betydeligt, og kun 17 procent har haft et stort eller betydeligt udbytte af Yahoo-messenger.

\section{Tryghed og tillid som grundlag for kommunikation}

Netop tilliden og fortroligheden med studiekammeraterne fungerede i det hele taget ikke optimalt på denne del af kurset. I forbindelse med evaluering blev der foretaget interview med ni tilfældigt udvalgte studerende. I interviewene blev det pointeret, at der manglede en større tryghed, for at ideen om et $24 * 7$ klasseværelse kan fungere. Desuden blev det fra nogle studerende udtrykt, at chat forbindes med en anden for kommunikation - en mere fri form. Som en studerende udtrykte det: "Messenger - det er vanskeligt at forklare reelle problemer i dette medie". 
Der blev ikke lagt nok vægt på teambuilding i starten af kurset, så de studerende ad denne vej blev fortrolige med hinanden. Som et andet eksempel på uhensigtsmæssigheder peges på, at seminaret i starten af forløbet langt hen ad vejen var bygget op som klassisk klasseundervisning. Og skønt mange masterstuderende møder med et udtalt krav om effektivitet fra første dag, ville det give et langt bedre udbytte senere, hvis der lægges mere vægt på det sociale aspekt, påpeger blandt andre Poul Grønkjær. Som introduktionsseminaret var bygget op i dette tilfælde fik for få på holdet udbytte af det gruppearbejde, der var indlagt $\mathrm{i}$ forløbet - mens mange af grupperne gik mere eller mindre i opløsning.

Den generelle opfattelse af det netstøttede kursus i programmering er, at det fungerede et langt stykke hen ad vejen. Dette kan ses af figur 5.

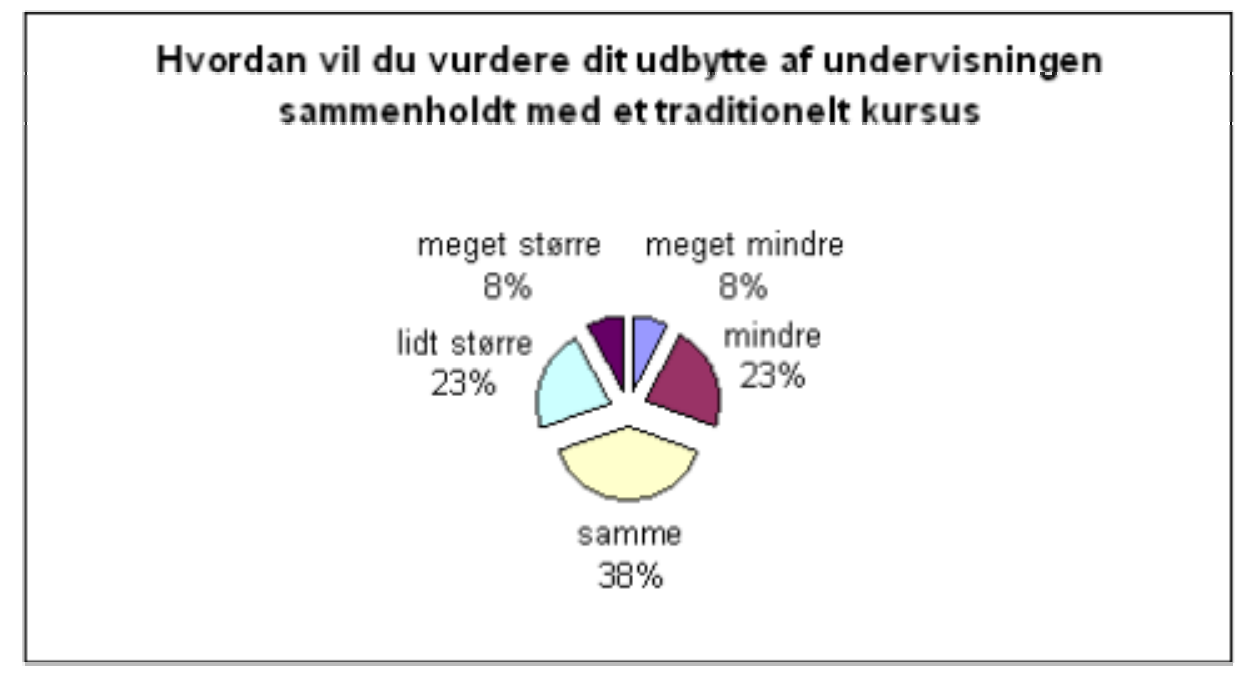

Figur 5: De studerendes vurdering af deres samlede udbytte

Teknologierne er til rådighed, så man kan fokusere på erfaringsopbygning og mere nuancerede valg af værktøjer til forskellige formål. Desuden understreger erfaringen fra underviserne, at det er vigtigt at have foretaget tests, før den egentlige undervisning starter, og hvor vigtigt det er, at der er supportmulighed for dem, som måtte have behov for det. Masterstuderende forventer ganske enkelt, at teknologierne virker - og helst første gang.

Foruden de nævnte tiltag, blev de studerende også tilbudt mere traditionelle elementer af netstøttet undervisning, som for eksempel tekstbaseret diskussionsforum og weekendseminarer. Denne type undervisning blev anvendt på mere traditionel vis - diskussionsforumet til faglige diskussioner, hvor tiden til refleksion er vigtig, og weekendseminarerne dels til mere livlige diskussioner dels til at fremme en socialisering mellem de studerende. Og socialiseringen er, som påpeget, specielt vigtig, hvis idéen om et $24 * 7$ klasseværelse skal kunne realiseres.

Som en efterfølgende vurdering af kurset fra kursusledernes side er der enighed om, at kursuslederne deler de studerendes tilfredshed med den "videomedierede mesterlære", hvor de studerende ser underviserens skærm". På skærmen ses, hvordan et program bliver skrevet stump for stump. Formen og mediet passer fortrinligt med ideen om et netstøttet undervisningsforløb. Specielt muligheden af at vise procesrelaterede emner var en overraskende positiv ting. Der er en del forskel på arbejdssituationen - som forskellen mellem en teaterskuespiller og en filmskuespiller. Det er meget krævende at undervise i op til halvanden time i træk (som det var i tilfældet af de video- 
medierede møder) uden at man får andet modspil end tekstuelle spørgsmål i en chat. Den traditionelle kontakt - og derved implicitte feedback - man som forelæser har med de studerende, mangler ved denne måde at undervise på. Måder dette kan forbedres på er nogle af de emner der vil blive eksperimenteret med i fremtiden.

Ud over forbedringer af de video-medierede møder, arbejdes i regi af et internationalt forskningsprojekt (se COOL, http://www.intermedia.uio.no/cool) med en undersøgelse af, hvilken rolle samarbejde spiller i et introducerende programmeringskursus. Hypotesen er, at det har en effekt for indlæringen af de konkrete programmeringsfærdigheder, at de studerende samarbejder om at tilegne sig disse; spørgsmålet er hvilken form samarbejdet bør have og hvordan denne form understøttet i den netstøttede verden.

\section{Litteratur}

Collis, Betty og Morren, Jef. Flexible Learning in a Digital World: Experiences and Expectations, Kogan Page, London 2001

Bennedsen, Jens og Michael Caspersen: "Rationale for the Design of a Web-based Programming Course for Adults" Proceedings for International Conference on Open and Online Learning, Mauritius, 2003. 